Contents List available at RAZI Publishing

Journal CleanWAS

Journal Homepage: http://www.razipublishing.com/journals/journal-cleanwas/

https://doi.org/10.26480/jcleanwas.01.2017.39.42

\title{
RATIO OF WATER WITHDRAWAL TO AVAILABILITY IN KELANTAN WATERSHEDS, MALAYSIA
}

Mohd Nur Saiful Abdul Samad1, Marlia M. Hanafiah1, , Mahmood Jamal AbdulHasan1, Nor Fadillah Ghazali1, Siti Norliyana Haruıı 1 School of Environmental and Natural Resource Sciences, Faculty of Science and Technology, Universiti Kebangsaan Malaysia, 43600 Bangi, Selangor, Malaysia

\section{*Corresponding author: mhmarlia@ukm.edu.my}

This is an open access article distributed under the Creative Commons Attribution License, which permits unrestricted use, distribution, and reproduction in any medium, provided the original work is properly cited

\section{ARTICLE DETAILS}

Article history:

Received 27 September 2016 Accepted 13 December 2016

Keywords:

Water scarcity; water availability; water stress index; water management; Malaysia Available online 10 January 2017

\section{ABSTRACT}

In the present study, the Water Stress Index for selected watersheds in Kelantan state, Malaysia was derived. Water Stress Index was derived based on the ratio of water withdrawal to availability serves as an indicator to assess the status of water scarcity in watersheds. Water consumption for the domestic purposes includes the daily water used for drinking and cleaning for household, while the non-domestic water used includes sector such as agriculture (paddy and non-paddy), industry and livestock. Estimation of water availability was obtained from 39 rainfall stations located in the Kelantan watersheds and the climate data was obtained from year 2005 to 2014 The water stress index is presented in a range of $0.0-1.0$. The result shows that the Water Stress Index value for Kelantan River was obtained at 0.01 implying low level of stress at this watersheds. Kelantan is the second state in the Peninsular Malaysia thai ı eceived ì'? highest amount of rainfall after Pahang state. In conclusion, we found that Kelantan watersheds have: a low amount of water consumption in ratio to the water availability. This is due to the low water consumption by ine : un-üunesti s sector in Kelantan. Apart from that, Kelantan also holds the third largest water catchment area in Peninsular Malaysia after Pahang and Kedah which influence the total amount of water availability in this state.

\section{INTRODUCTION}

Water management includes the processing of water to be supplied into the domestic and non-domestic sector, transportation, recreation, flood control and energy generation. Water consumption can be divided into two main categories which are for the domestic and non-domesic purpose. Water consumption in domestic sector refers to the usage of water for public use. Examples of domestic usage are drinking purpose, cooking, showering, cleaning purpose and sanitation.

The percentage of domestic water consumption in the United States of America shows that $41 \%$ of water was used for flushing, 37\% for showering, $6 \%$ for cleaning of dishes, $5 \%$ for the preparation of food and drink, $4 \%$ for laundry and $4 \%$ for house cleaning [1]. It is estimated that approximately 567 litres of water was used by every individuals in United States of America daily with $41 \%$ from that is used for domestic purposes [2]. For the category of water consumption by non-domestic sectors, it involves agriculture, husbandry and industrial sector where all of these activities need a water supply in a huge volume. Industrial sector is one of the most significant sectors in Malaysia. Malaysia is expected to be one of the industrialised countries in the world by 2020. In our 7th Malaysia's Plan (RMK-7), a huge amound of money was allocated to develop the industrial sector in Malaysia since the industrial sector has become the highest contributor in our Gross National Product (GDP) since the last Malaysia's Plan (RMK-6) was carried out. Development of the industrial sector is aligned with the water management in Malaysia. Improper water management will lead to the unsystematic flow of the factories especialy in the industrial sector and eventually will disrupt the operational processes that depends a lot on the clean water supply. Decreasing in the quality of the ecosystem occured when crops did not receive enough supply of clean water [3]. This will be affecting the diversity of flora and fauna that inter dependent between each other. Other than that, the decreasing in quality of the ecosystem also can be caused by the disruption at the water source. The existence of sediment at the bed of river or any water bodies can be the best indicator in determining the availability of water at that particular area. Agriculture sector on the other hand was one of the highest contributors in Malaysia GDP before being over ranked by industrial sector. Since early 1920, our country is depending on the agriculture sector where at some point, Malaysia was once become the main player in agriculture sector as the biggest exporters in latex products. A lot of initiatives has been implemented by the government as well as the private sector in order to develop the agriculture sector in Malaysia. For example, the establishment of Lembaga Kemajuan Tanah Persekutuan (FELDA) and Lembaga Penyatuan dan Pemulihan Tanah
Persekutuan (FELCRA), introduction of Lembaga Pemasaran Pertanian Persekutuan (FAMA), Pihak Berkuasa Kemajuan Pekebun Kecil Perusahaan Getah (RISDA), Institut Penyelidikan dan Kemajuan Pertanian (MARDI), Lembaga Padi dan Beras Negara and not to forget the Lembaga Pertubuhan Peladang that contribute to the aggressive development of agriculture sector in Malaysia at that time.

Malaysia's former Prime Minister, Tun Abdullah Ahmad Badawi was seeing the opportunity for Malaysia to become one of the most well-known country in agriculture sector and for that reason, he spent a huge amount of money in RMK-9 and also in Budget 2006. The transformation of agriculture sector in Malaysia was carried out by the 5th Prime Minister that was aiming towards becoming an agricultural country with more competitive and well efficient in upgrading the income of local farmers and reducing the dependency on imported products for a long run. Another criterias that is very important apart from site selection in agriculture activity is the water resource for the crops. Most of the water consumed by the crops is for the development of the crops itself. The water comes from the ground and it flows directly to the agriculture area.

The study on the assessment of Water Stress Index in Sungai Kelantan for the impact of water consumption by the domestic and non-domestic sector in Kelantan need to be carried out to identify the volume of water availability and also the water consumption for these two variables. Moreover, this study needs to be done because the demand for freshwater supply is increasing every single year. According to the Stastitical Department of Malaysia, they projected that the freshwater demand will increased up to $50 \%$ in the developed countries in 2025. Apart from that, the climate change is also affecting the supply of freshwater in the world. For that particular reason, the shortage of water supply has become one of the critical issues to be discussed in the international environmental program. Since Malaysia is located in the South-east Asia, we experience the tropical climate which is hot and wet throughout the whole year. Based on that reason, the water availability issue should be one of the main components in our forum and discussion. One of the methods to evaluate the ratio of water availability and water consumption in any selected research area is by using the Water Stress Index. Water Stress Index is one of the tools to assess the potential impact faced by the water body in the research area. It helps to indicate whether the selected area is having any shortage in water supply. Water Stress Index used the ratio of water consumption of freshwater to the volume of the water availability (Pfister 2009). The main focus on this study is to assess the current state of art of the ratio of water withdrawal by domestic and non-domestic sector particularly in the area along the Kelantan River and water availability at Kelantan watershed. 
Sustainability and continuation of life is depending on the factor of freshwater supply [4]. Taking the agriculture sector for example, commercially or noncomercially, the water supply plays an important role in determining the growth of crops until the level of productivity. The products of industrial sector especially in Kelantan State will face a problem if the water supply is insufficient to cater the the whole process. Based on that reason, the farmers are highly depending on Kelantan River for the sake of freshwater supply. The main components in agriculture sector involve the plantations of paddy fields, rubber and also the palm trees.

The derivation of Water Stress Index can serves as a basis for determining the potential impact of water consumption in Malaysia especially in the state of Kelantan. Domestic and non-domestic sectors have been included in this study because along the area of Kelantan River, the demand for clean water is very high and Kelantan River is the main source of freshwater in Kelantan. The objectives of this study are to estimate the total volume of water availability and water consumption in the state of Kelantan and to derive the Water Stress Index for Galas River and Pergau River of Kelantan watershed.

2.0 METHODOLOGY

2.1 Study area

The study area is Kelantan State which is located in the east coast of Peninsular Malaysia with a total area of 15, $099 \mathrm{~km} 2$. Kelantan is bordered by Thailand's province in its north area, Perak in its west, Pahang in its south and Terengganu as its neighbours. There are 10 districts in Kelantan which are Kota Bharu, Tumpat, Bachok, Machang, Pasir Puteh, Jeli, Tanah Merah, Pasir Mas, Kuala Krai dan Gua Musang. Kelantan watershed flows along 248 $\mathrm{km}$ across the districts of Kota Bharu, Tumpat, Pasir Mas, Machang, Bachok, Pasir Puteh and Kuala Krai. Kelantan watershed has a total of 12, $981 \mathrm{~km} 2$ area contributed by the four main rivers which are Sungai Neggiri, Sungai Galas, Sungai Lebir and Sungai Pergau. Kelantan watershed has become the main source of freshwater to supply the clean water for the domestic and non-domestic used especially for the sector that is located along the watershed.

Figure 1 illustrated that Gua Musang is the largest district in Kelantan with a total size of $8,213 \mathrm{~km} 2$ while Tumpat is the smallest distict with only 179 $\mathrm{km} 2$ total size. On the other hand, Figure 2 shows the population size of every single district in Kelantan State. The total population in Kelantan State is approximately at 1.7 millions according to the data from the Statistical Department of Malaysia. Kota Bharu recorded the highest number of citizen with a total number of 509, 400 people followed by the district of Jeli with a number of 47,600 people only (Table 1 ). In the south area is where the hilly elevation is located and it is where the Banjaran Titiwangsa is located. The agriculture sector is the main activity in Kelantan with the agriculture plantations such as rubber, paddy field and rubber are dominating the alongside Kelantan watershed.

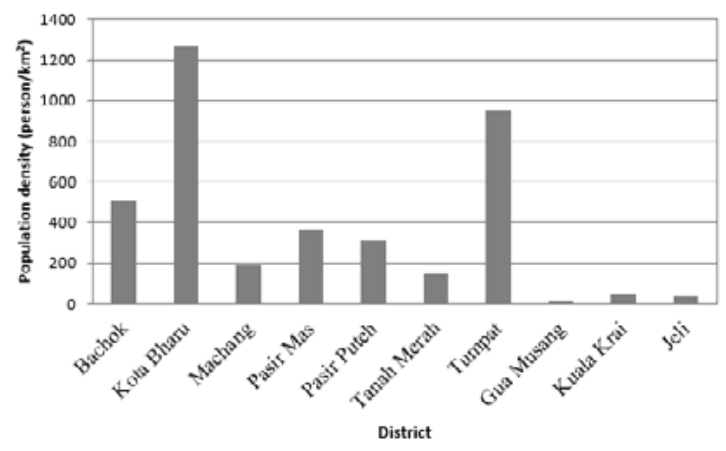

Figure 2 Population density in Kelantan State based on districts (people/ $/ \mathrm{mm}^{2}$ )

\begin{tabular}{|c|c|c|c|c|}
\hline District & Area $\left(\mathbf{k m}^{2}\right)$ & Population & $\begin{array}{c}\text { Population } \\
\text { density } \\
\text { (people/km²) }\end{array}$ & $\begin{array}{c}\text { Population } \\
\text { growth rate 2009- } \\
2010 \text { (96) }\end{array}$ \\
\hline Bachok & 280 & 141,400 & 505 & 2.1 \\
\hline Kota Bharu & 403 & 509,400 & 1,264 & 1.9 \\
\hline Machang & 530 & 100,900 & 190 & 2.0 \\
\hline Pasir Mas & 572 & 211,100 & 369 & 1.9 \\
\hline Pasir Puteh & 425 & 134,000 & 315 & 2.0 \\
\hline Tanah Merah & 884 & 132,400 & 150 & 1.8 \\
\hline Tumpat & 179 & 170,000 & 950 & 1.9 \\
\hline Gua Musang & 8,213 & 104,800 & 13 & 2.0 \\
\hline Kuala Krai & 2,287 & 119,000 & 52 & 1.6 \\
\hline Jeli & 1,325 & 47,600 & 36 & 1.9 \\
\hline Jumlah & 15,099 & $1,670,500$ & 111 & 1.9 \\
\hline
\end{tabular}

Figure 3 shows the Kelantan watershed. Kelantan River has become the main source

Figure 3 shows the Kelantan watershed. Kelantan River has become the main source of freshwater supply for the domestic and non-domestic sectors especially those along the river area. Secondary data were obtained from the Department of Drainage and Irrigation, Statistical Deparment of Malaysia, Meteorological Department of Malaysia and Department of Agriculture. The rainfall data from the past 10 years (2005 - 2014) were used in the present study. Data for water consumption (domestic and nondomestic sectors) were obtained year 2005 until 2014.2.2 Conceptual

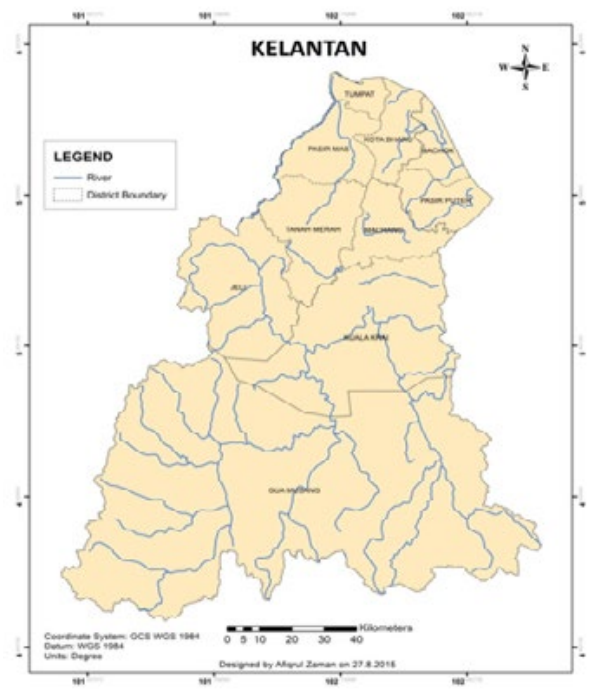

Figure 3: Location of the rivers in the state of Kelantan

Framework

Figure 4 shows the conceptual framework for the present study. This study is carried out in two different phases, which are data inventory and data analysis. 


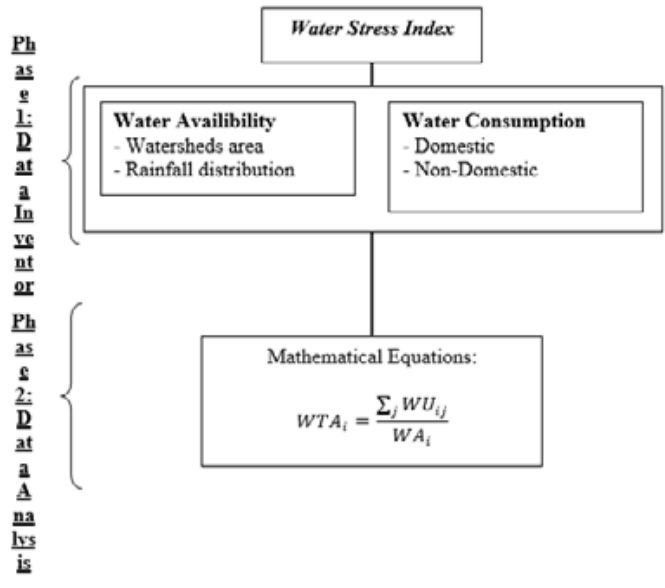

Figure 4 Conceptual framework of the present study

The data inventory involves the collection of primary and secondary data. The data was obtained from the survey, reports, books, journals and from the relevant agencies. The primary data include the site visit activity and communication with the data providers. The secondary data were gathered from government agencies such as the Syarikat Air Kelantan (SAK), Department of Drainage and Irrigation of Malaysia, Statistical Department of Malaysia, Lembaga Pertubuhan Peladang (PELADANG) and Pihak Berkuasa Kemajuan Pekebun Kecil Perusahaan Getah (RISDA). Table 2 shows the parameters used for the derivation of Water Stress Index.

\begin{tabular}{|c|c|}
\hline Data & Input \\
\hline \multirow[t]{3}{*}{ Water As allibility } & Rainfall distribution \\
\hline & - Watersheds area \\
\hline & - Groundwater storage \\
\hline \multirow[t]{4}{*}{ Water Consumption } & - Domestic Sector \\
\hline & - Agricultural Sector \\
\hline & - Industrial Sector \\
\hline & Husbandry Sector \\
\hline
\end{tabular}

Water Stress Index was derived based on the ratio between water withdrawal and water availability following [6]:

WSI=(Water Withdrawal)/(Water Availability)

$\mathrm{WSI}=1 /\left(1+\mathrm{e}^{\wedge}\left(-6.4^{*} \mathrm{WTA}^{*}\right)(1 / 0.01-1)\right)$

$\left.\left[([\mathrm{WTA})]^{\wedge *}=\sqrt{\mathrm{VF}} \times \mathrm{WTA}\right)\right]_{-} \mathrm{i}$

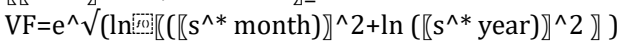

(WTA $\rrbracket_{-} \mathrm{i}=\left(\sum_{-} \mathrm{j}\right.$ :

where:

$\mathrm{VF} \quad=$ variation factor derived from the standard deviation for the distribution of precipitation

( $\mathrm{s}^{*}$ month) $\quad=$ standard deviation of monthly precipitation

( $\mathrm{s}^{*}$ year) $\quad=$ standard deviation of annual precipitation

The value of Water Stress Index is ranges from 0 to 1 . The WSI value closes 1.0 implying an extreme water stress condition. The values of Water Stress Index were classified into five categories (Table 3).

Table 3: Classification of water stress index [20]

\begin{tabular}{ll}
\hline WSI & Condition \\
\hline$>0.9$ & Extreme \\
$<0.9$ & Severe \\
0.5 & Stress \\
$<0.5$ & Moderate \\
$<0.1$ & Low
\end{tabular}

\subsection{Water Availability of Kelantan Watershed}

Data for water availability was obtained from the Department of Drainage and Irrigation. Rainfall data were gathered from 39 meteorological stations located at Kelantan watershed. Figure 5 illustrates the location of the 39 meteorological stations. Kelantan received a high amount of rainfall trhoughout the year due to its location on the East Coast of Peninsular Malaysia. Based on the report from the Meteorological Department of Malaysia, Kelantan received the highest amount of rainfall from month of October to December each year due to the influence of the Northeast monsoon wind. Northeast monsoon wind cause heavy rains in the states of Kelantan, Terengganu and Pahang, whereas February, March and April received less amount of rainfall at the Kelantan State.

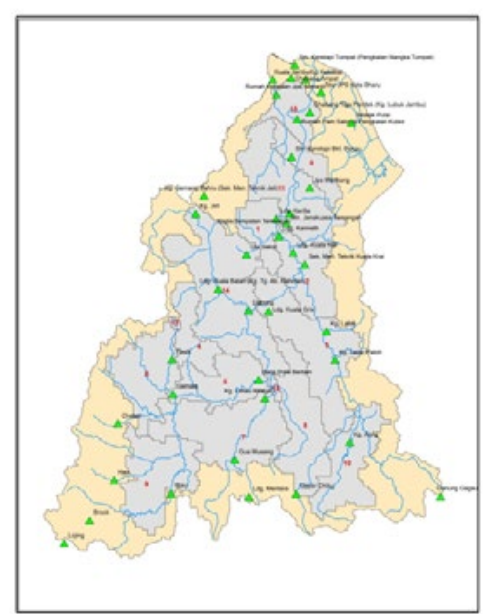

Figure S: Location of the 39 meteorological stations at Kelantan watershed

\subsection{Water Withdrawal of Kelantan Watershed}

Since the past few decades, scientists have started to pay attention to the environmental issues where the quality and the quantity of the freshwater have become the most important indicator in determining the human's health level [5]. Department of Statistic Malaysia projected that the demand for clean water in agriculture sector alone will increase $50 \%$ by year 2025 . Apart from that, climate change also influenced the demand of freshwater in the world. Domestic and non domestic water withdrawal data were obtained from the Syarikat Air Kelantan (SAK). Data for non domestic sector in Kelantan State consist of agriculture, industrial and livestock. Agriculture sector covered both paddy and non paddy culativation. Figure 6 shows the percentage of water consumption of three sectors in Kelantan for year 2010.

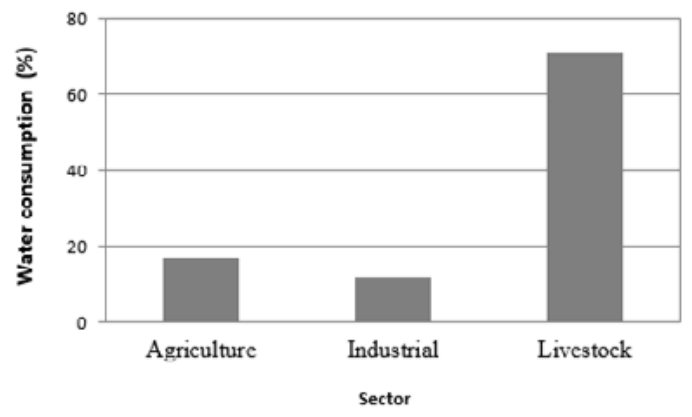

Figure 6: Water consumption for year 2010 based on 3 sectors

For the total domestic water consumption in Kelantan, Kota Bharu is the highest district for water consumption for a period of 10 years (2005 to 2014). Kota Bharu is an area with the highest population in Kelantan State with a density of more than a half million. The lowest water consumption was found for Jeli. The water consumption for domestic sector was depends on the number of residents in the area.

Figure 6 presents the percentage of water consumption for agriculture sector in Kelantan State for year 2010. For agriculture sector, non paddy consists of cultivation of oil palm, rubber, tobacco, fruits, vegetables, herbs, flowers and industrial crops (Figure 7 and 8). Rubber is the largest plantation in Kelantan State with an area of 131,475 Ha, while herbs and flowers were only planted for areas of $13.2 \mathrm{Ha}$ and $34 \mathrm{Ha}$, respectively. 


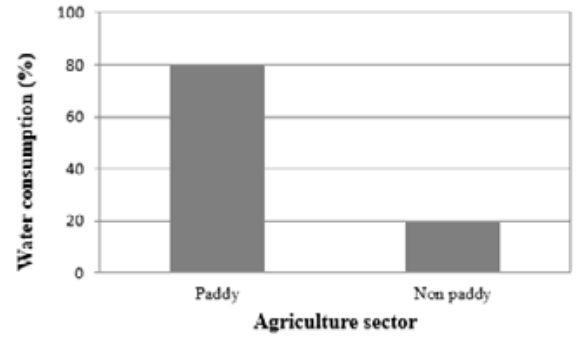

Figure 7: Water consumption for agriculture sector for year 2010

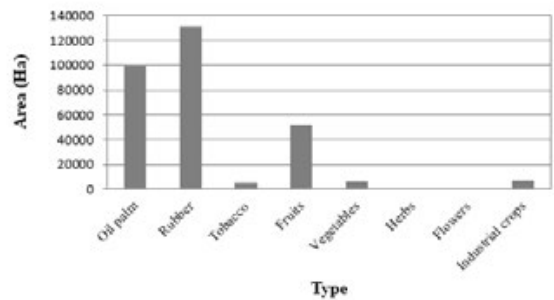

Figure 8: Area of cultriation of non paddy in the Kelantan State for the year of 2010

The water consumption for industrial sector in the Kelantan State recorded $11.79 \%$ from the total water consumption of non domestic. Most of the industrial activities are located in Kota Bharu and Gua Musang Districts. Water consumption for livestock sector contributes to the highest consumption in Kelantan State with $71 \%$ of the total water consumption for non domestic sector. Figure 9 shows the percentage ofaverage water consumption for each livestock per day (L/livestock/day).

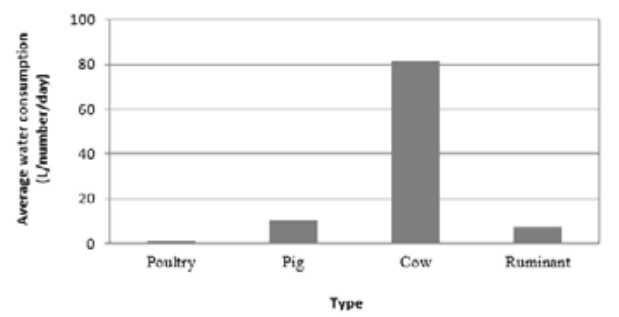

Figure 9: Average of water consumption per each livestock in a day ( $\mathrm{L} / \mathrm{number} / \mathrm{day})$

Water Stress Index for Kelantan Watershed

The water stress index derived for Kelantan watersed is 0.010 implying low level of water stress at this watershed. Table 4 shows the water stress index for two river of Kelantan watershed, namely Pergau River and Galas River.

\begin{tabular}{cc}
\multicolumn{2}{c}{ Table 4 WSI Pergau River and Galas River } \\
\hline Pergau River & Galas River \\
\hline VF $=3.795305$ & VF $=5.3503334$ \\
Square Root of VF $=1.948154$ & Square Root of VF $=2.313079$ \\
WTA $=0.00000$ & WTA $=0.00002$ \\
WSI $=0.01$ & WSI $=0.01$
\end{tabular}

The water stress index value explained the sufficient water supply for domestic and non domestic sectors in Kelantan State. Higher rainfall rate received by this state contributes to the higher water availability in Kelantan State compared to the other states.

\section{CONCLUSION}

Based on this study, it was found that the Water Stress Index in Kelantan is 0.010 implying low level of stress for water availability in Kelantan watershed. This is due to the fact that high amount of rainfall rate in the state of Kelantan influences the availability of water supply. The high amount of groundwater storage in the state of Kelantan also provides sufficient water for Kelantan State. The present water availability on Kelantan State is enough for a period of time to cater the need of water resources by various sectors.
In addition, the amounts of water consumption for domestic and nondomestic sectors are at a moderate level, except for Kota Bharu District. This is due to the high population density at Kota Bharu District and various activities and industries are concentrated in this area. Kelantan River is the main river in Kelantan thus it provides the supply for freshwater for the Kelantanese. The domestic and non-domestic sectors in Kelantan State mostly rely on the freshwater originating from this river. Furthermore, Kelantan River plays an important role as the transportation route because most of the activities along the river are still using the river as their main transportational choice. Lack of freshwater supply will initiate the problems involving the health issue, hygiene, nutrition and food source because it will eventually lead to the spreading of diseases and malnutrition caused by the improper drainage and irrigation system. REFERENCES

[1]Todd, D. K. 1970. The water encyclopedia. Water Information Center, Port Washington, New York.

[2]Mather, J.R. 1984. Water resources: Distribution, use and management. (New York: John Willey)

[3]Gheewala, S. H., Silalertruksa, T., Nilsalab, P., Mungkung, R., Perret, S. R., \& Chaiyawannakarn, N. 2014. Water Footprint and Impact of Water Consumption for Food, Feed, Fuel Crops Production in Thailand. 1698-1718.

[4]Girolimetto, V. \& Venturini, V. 2013. Water Stress Estimation From NDVITs Plot. Centre For Water and Environmental Studies. Universidad Nacional del Litoral, Santa Fe, Argentina. Advances in Remote Sensing 2013, 2, 283291.

[5]Ujang, Z., Rahman, R. A., Anuar, A. N. 2008. Current Trends In Water Quality And Resource Management. Institute of Environmental and Water Resource Management (IPASA), Universiti Teknologi Malaysia. Proceedings of the 1st Technical Meeting of Muslim Water Researchers Cooperation (MUWAREC) December 2008 (Malaysia).

[6]Pfister, S., Koehler, A., \& Hellweg, S. 2009. Assessing the Environmental Impacts of Freshwater Consumption in Life Cycle Assessment. ETH Zurich, Institute of Environmental Engineering, 8093 Zurich, Switzerlands. 40984104 